\title{
Unia Europejska, globalizacja i Polska
}

Ekonomiczna integracja pomiędzy państwami ma długą historię. Międzynarodowy handel był względnie dobrze zorganizowany w okresie średniowiecza, a wymiana handlowa na lądzie pomiędzy poszczególnymi miejscami sięgała aż do Chin. Porty należące do Hanzy, w tym Gdańsk, były częścią bardzo bogatej wymiany handlowej pomiędzy państwami Europy (Davies 1997). Handel ten znacznie powiększył się w XVIII i XIX stuleciu w wyniku kolonizacyjnego i industrialnego rozwoju. Państwa europejskie, takie jak Wielka Brytania, stały się zależne od importowanej żywności, a później od podstawowych surowców dla przemysłu. Państwa kolonialne - Portugalia, Hiszpania, Francja, Belgia, Holandia i Wielka Brytania - miały bardzo niskie cła importowe na artykuły z ich kolonii, co przyczyniło się do wzrostu międzynarodowego handlu. Do końca XIX w. stosowano skomplikowany system międzynarodowego handlu i umów handlowych, więc efektywnie globalizacja gospodarek już wówczas istniała. Ściślejsza integracja ekonomiczna miała miejsce w latach 40. XX w. pomiędzy państwami Beneluxu i następnie w państwach RWPG. W 1953 r. powołano Europejską Wspólnotę Węgla i Stali, która była prekursorem powstania w 1957 r. wspólnego rynku. UE jest faktycznie częścią długiego procesu integracji czy też globalizacji (Cole and Cole 1993).

Wstąpienie Polski do Unii Europejskiej w maju 2004 r. przyniosło jej wiele korzyści: zniesienie ceł na polskie produkty, które teraz są zdolne do penetracji bogatych rynków krajów starych członków UE, finansowe wsparcie wielkiego sektora rolniczego, finansową pomoc dla regionów o wysokim bezrobociu, finansowe wsparcie dla projektów infrastrukturalnych, takich jak budowa dróg, lepszą pozycję polityczną wynikającą z przynależności do Europy Zachodniej, w szczególności w świetle trudnej polityki z Rosją i prezydentem Putinem. Należy się spodziewać, że członkostwo powiększy też liczbę zagranicznych inwestycji w Polsce.

Nie ulega wątpliwości, że olbrzymie przemiany miały miejsce w latach 1989-2004 nie tylko z powodu decyzji odrzucenia systemu socjalistycznego i wprowadzeniu wolnego rynku, ale także z uwagi na to, że jedną z cech charakteryzujących system wolnego rynku jest ekonomiczna globalizacja (Blacksell and Williams 1994). Oznacza to, że obecnie rzeczywistą konkurencję stanowią państwa azjatyckie, takie jak Indie, Chiny, Korea Południowa i Japonia. Globalizacja oznacza, prawdopodobnie za wyjątkiem Stanów Zjednoczonych, że ekonomiczne przemiany w poszczególnych krajach są szeroko kontrolowane przez międzynarodowe działania (Taylor and Trift 1986). Polska jest odpowiedzialna za zmiany 
w mikroskali (Geografia... 2004), ale musi pracować wewnątrz struktur międzynarodowych wydarzeń. Działania te były kontynuowane wraz z członkostwem Polski w UE, sprawiając trudność w ustaleniu pełnego wpływu na nie integracji europejskiej. Do niektórych z tych przemian należą:

1. Przejście od gospodarki centralnie sterowanej do jej decentralizacji, pozwalające, aby lokalne problemy były rozwiązywane przez społeczności lokalne, które w sposób pełny rozumieją swoje problemy;

2. Wprowadzenie demokratycznych wyborów, co sprawiło, że decyzje na szczeblu krajowym w bliższy sposób odzwierciedlają życzenia elektoratu (Grabher and Stark 1997);

3. Duży wzrost stopnia zamożności: wzrost liczby samochodów i dostępnych artykułów konsumpcyjnych;

4. Wzrost różnicy w dochodach pomiędzy zamożnym społeczeństwem a biednym typowa charakterystyka dla gospodarek rynkowych;

5. Wzrost bezrobocia postępujący wraz z wprowadzeniem gospodarki rynkowej;

6. Wzrost zagranicznego kapitału w przemyśle, powodujący wykorzystanie istniejącej nisko płatnej siły roboczej. Efektem tego jest powstawanie dużej liczby fabryk, których zyski nie pozostają w Polsce, ale są przesyłane do zagranicznych siedzib firm. Czasami się uważa, że te fabryki, zwane branch plants (filialne fabryki), zatrudniają tylko robotników, ale one także zatrudniają średnich menadżerów, którzy są dobrze opłacanymi pracownikami i mają swój istotny udział w lokalnej ekonomii. Typowa branch plants korzysta też z lokalnych usług, takich jak naprawy i transport. Dobrym przykładem, jaką satysfakcjonującą pozycję może posiadać branch plants, może być Belgia, gdzie większość fabryk jest obecnie zagraniczną własnością i gdzie dochód z przemysłu na 1 mieszkańca jest wysoki. Firmy takie jak IBM dają swoim branch plants niezależność, a w zamian za to otrzymują najwyższych i średnich menadżerów, zatem forma branch plants nie jest niekorzystna (Watts 1981). W tym miejscu należy zaznaczyć, że w przypadku Łodzi zagraniczny kapitał pojawił się za sprawą przemysłowców pochodzenia żydowskiego, takich jak Poznański i Scheibler, którzy przybyli w połowie XIX w., zatem zjawisko to nie jest czymś nowym.

7. Otwarcie z zagranicznym kapitałem sklepów, supermarketów, hipermarketów i stacji benzynowych. Istnieje część procesów globalizacji, które są korzystne, jak branch plants, tzn. średni menedżerowie są dobrze opłacanymi pracownikami i lokalne usługi są w pełni wykorzystywane;

8. Gwałtowny upadek starych tradycyjnych przemysłów, takich jak: górnictwo węgla kamiennego, włókienniczy i mechaniczny, przy równoczesnym rozwoju sektora usług. Jest prawdą, że sektor usług zatrudnia nisko płatnych pracowników, np. w gastronomii, hotelarstwie, handlu detalicznym i transporcie, ale generuje też miejsca pracy dobrze płatne, jak np. finanse, ubezpieczenia, nieruchomości i usługi dla biznesu. Istotnym problemem jest fakt, że pracownicy zatrudnieni w przeszłości w przemysłach tradycyjnych nie są w stanie dostosować się do pracy w usługach;

9. Masowa penetracja produktów zachodnich, a także z południowo-wschodniej Azji;

10. Wykorzystanie niektórych obiektów pofabrycznych na apartamenty, handel detaliczny czy magazyny i składy;

11. Stabilizacja ekonomiczna dzięki członkostwu w NATO.

Miały miejsce także zmiany, które są rezultatem członkostwa w Unii Europejskiej, np.:

1. Masowa emigracja młodych ludzi do Wielkiej Brytanii, Irlandii, Niemiec i Hiszpanii, co spowodowało zmniejszenie siły roboczej w Polsce. Uważa się jednak, że ten ruch 
migracyjny jest tylko krótkotrwały, zwłaszcza że większość Polaków zamierza wrócić do kraju ze skumulowanym kapitałem;

2. Łatwiejsza penetracja przez polskie produkty bogatych rynków UE; zauważalna jest także penetracja produktów z UE w Polsce;

3. Spadek bezrobocia, ale nadal pozostaje ono relatywnie wysokie (Węcławowicz 1996).

W konkluzji należy zaznaczyć, że aby ocenić znaczenie członkostwa w Unii Europejskiej i wpływu procesów globalizacji na Polskę, potrzebny jest znacznie dłuższy okres czasu. W każdym razie Polska jest częścią procesów globalizacji i integracji ekonomicznej, co odzwierciedla fakt jej przynależności do Unii Europejskiej.

\title{
Literatura
}

Blacksell M. and Williams A. M., 1994, The European Challenge, Oxford Univesrity Press

Cole J. and Cole F., 1993, Geography of the European Community, Routledge

Davies N., 1997, Europe. A History, Oxford University Press

Geografia gospodarcza Polski, 2004, I. Fierl, red., PWE, Warszawa

Grabher G. and Stark D., 1997, Restructuring Network in Post-Socialism, Oxford University Press

Taylor M. and Thrift N., 1986, Multinationals and the Restructuring of the World Economy, Croom Helm

Watts H.D., 1981, Branch Plant Economy, Longman

Węcławowicz G., 1996, Contemporary Poland Space and Society, University College London Press

\begin{abstract}
Podziękowanie
Chciałabym wyrazić szczególne podziękowanie Panu Profesorowi R.C. Riley z University of Portsmouth UK za umożliwienie wielu konstruktywnych dyskusji, które zaowocowaty podjęciem badań na powyższy temat.
\end{abstract}

\section{European Union, globalisation and Poland}

International economic integration, or globalisation, has a long history, dating from the Medieval period; the establishment and later extension of the European Union is part of this process.

It is argued that EU membership has brought undoubted advantages, such as support for agriculture and for regions of high unemployment, and the removal of tariffs against Polish goods, but the huge changes experienced by Poland date from the introduction of the market economy in 1989, not from EU membership. The market economy is synonymous with globalisation, which is so powerful that countries are forced to adapt to it, and make changes within this framework. There have been changes since 2004, the most important of which is mass emigration to the UK, Ireland, Germany and Spain, but it is thought that this movement is only short-term, since most Poles intend to return to Poland, having accumulated capital. It is too soon to be able to establish the full impact of EU membership.

It seems that a much longer period must be allowed to elapse before it is possible to assess the value of EU membership to Poland. But in any case, it is clear that Poland has become part of the globalisation and economic integration process - something that will be emphasised owing to membership of the EU. 